\title{
COMPARISON OF ANTITRUST OFFICE IN PUBLIC CONTRACTS AND ECONOMIC COMPETITION
}

\author{
[Srovnání činnosti Úřadu pro ochranu hospodářské soutěže v oblasti veřejných \\ zakázek a ochrany hospodářské soutěže]
}

\author{
Martina Bendová ${ }^{1}$, Jiří Malíšek ${ }^{2}$ \\ ${ }^{1}$ Slezská univerzita, Obchodně podnikatelská fakulta, Univerzitní nám. 1934/3, 73340 Karviná \\ Email:o112147@opf.slu.cz \\ ${ }^{2}$ Slezská univerzita, Obchodně podnikatelská fakulta, Univerzitní nám. 1934/3, 73340 Karviná \\ Email:o112153@opf.slu.cz
}

\begin{abstract}
The competence of the Antitrust office include mainly economic competition and public contracts and the supervision of its effective functioning. The aim of this paper is to compare the work of the Antitrust office in these areas. The monitored areas are the sanctions imposed by the Authority in the first instance, the average penalty imposed by the Authority in the first instance, the number of initiated administrative proceedings, the number of appeals submitted in the first instance and development trend analysis of budget and number of employees of the Authority and the number of employees in the surveyed sections.
\end{abstract}

Keywords: analysis, antitrust office, economic competition, public contracts.

JEL classification: $\mathrm{H} 00, \mathrm{H} 8, \mathrm{~L} 51$

Doručeno redakci: 28.8.2015; Recenzováno: 1.9.2015; 1.9.2015; Schváleno k publikování: 15.12.2015

\section{Úvod}

Úřad pro ochranu hospodářské soutěže (dále jen „Úřad“) vytváří podmínky pro podporu a ochranu hospodářské soutěže, vykonává dohled při zadávání veřejných zakázek a vykonává další působnosti stanovené zvláštními zákony. ${ }^{1}$ Urřad patří k ústředním orgánům státní správy v České republice. Veškerá jeho činnost má podstatný vliv na tržní prostředí, jeho další vývoj a v konečném důsledku také ovlivňuje chování firem ke koncovým spotřebitelům.

Cílem daného př́spěvku je seznámení s kompetencí Úřadu v oblasti veřejných zakázek a hospodářské soutěže včetně definování možných forem jejího narušení a také analýza vývoje vybraných charakteristik z obou výše uvedených oblastí.

Jako podklad pro tvorbu následujících grafů byly použity sekundární informace z výročních zpráv uložených na webových stránkách Úřadu. Dle dostupnosti jednotlivých dat z daného zdroje byly vybrané údaje přeneseny do tabulkového procesoru MS EXCEL dle různých časových řad. Následné další zpracování informací probíhalo v programu EViews. Zde byly data také časově a tematicky seřazena. Každému zkoumanému vzorku byl přidělen kód a data byla dále zpracována pod tímto označením a $\mathrm{v}$ daném časovém období. Výsledkem jsou níže uvedené grafy, které srovnávají vybranou problematiku současně jak v oblasti hospodářské soutěže tak i veřejných zakázek.

Sledovanými oblastmi jsou sankce udělené Úřadem v 1. stupni, průměrné sankce uložené Úřadem v 1. stupni, počet zahájených správních ř́zení, počet rozkladů podaných v 1. stupni,

\footnotetext{
${ }^{1} \S 2$ zákona č. 273/1996 Sb.
} 
a analýza trendu vývoje rozpočtu a počtu celkových zaměstnanců Úřadu a počtu zaměstnanců ve sledovaných sekcích.

\section{Veřejné zakázky}

Veřejné zakázky jsou nákupem služeb, zboží a stavebních prací z veřejných prostředků (Transparency International, 2007). Primárním důvodem existence právní úpravy veřejných zakázek je optimalizace využivání veřejných zdrojů. Tato optimalizace je nutná z důvodu jejich omezeného disponibilního objemu, jakož i potřeby splnit s využitím př́íslušných prostředků co nejvíce veřejných potřeb (Bergerová, 2005). Kompetence Úřadu vzhledem k veřejným zakázkám jsou rámcově určeny zákonem č. 273/1996 Sb., hlavně ovšem zákonem č. 137/2006 Sb., o veřejných zakázkách. Hlavním smyslem dohledové činnosti úruadu je zajištění rovné, transparentní a nediskriminační soutěže, což v konečném důsledku přináší i úspory veřejných financí. Je totiž zřejmé, že zajištění rámce pro efektivní vynakládání finančních prostředků zadavatelů při pořizování dodávek, služeb a stavebních prací lze dosáhnout pouze provedením transparentní soutěže. Z celoevropského srovnání vyplývá, že Česká republika patř́ $\mathrm{k}$ zemím, kde se veřejné zakázky často dostávají na základě předložení co nejnižší ceny (Pravec, 2014). Úřad rozhoduje, zda zadavatel při zadávání veřejné zakázky postupoval $\mathrm{v}$ souladu se zákonem, ukládá nápravná opatření a sankce, projednává správní delikty a plní další úkoly stanovené př́íslušnými zákony. Pravomocná rozhodnutí jsou zveřejňována ve sbírkách rozhodnutí na internetových stránkách Úřadu. Úřad vykonává dohled nad postupem zadavatele při zadávání veřejných zakázek a soutěži o návrh, při kterém vydává předběžná opatření, rozhoduje o tom, zda zadavatel při zadávání veřejné zakázky a soutěži o návrh postupoval $\mathrm{v}$ souladu se zákonem, ukládá nápravná opatření a kontroluje úkony zadavatele při zadávání veřejných zakázek podle zvláštního právního předpisu. ${ }^{2}$ Návrh na přezkoumání úkonů zadavatele je zahájen na písemný podnět stěžovatele a může se týkat všech kroků zadavatele. S podáním návrhu je navrhovatel povinen složit na účet Úřadu kauci ve výši 1 \% z nabídkové ceny navrhovatele za celou dobu plnění veřejné zakázky nebo za dobu prvních čtyř let plnění v prrípadě smluv na dobu neurčitou, nejméně však ve výši 50000 Kč, nejvýše ve výši 10000000 Kč. V případě, že navrhovatel nemůže stanovit celkovou nabídkovou cenu, je povinen složit kauci 100000 Kč. V případě návrhu na uložení zákazu plnění smlouvy je navrhovatel povinen složit kauci ve výši 200000 Kč. ${ }^{3}$ Kauce propadá, pokud je návrh zamítnut, ř́zení zastaveno nebo je návrh vzat zpět před vydáním rozhodnutí. Úřad rozhoduje i o spáchání správních deliktů, za něž může zadavateli uložit pokutu do 20000000 , v př́padě opakovaného páchání až 40000000 . Totéž platí i pro správní delikty dodavatelů, kterým ale může být uložen i zákaz účasti na veřejných zakázkách malého rozsahu.

Od 1. července 2006 Úřad dohlíží také nad uzavíráním koncesních smluv podle zákona č. 139/2006 Sb., o koncesních smlouvách a koncesním řízení, a od 1. července 2010 také nad uzavíráním smluv o veřejných službách $\mathrm{v}$ přepravě cestujících na základě nabídkového řízení nebo př́mým zadáním podle zákona č. 194/2010 Sb., o veřejných službách $\mathrm{v}$ přepravě cestujících. Pro dohled nad uzavíráním koncesních smluv platí obdobná ustanovení jako u veřejných zakázek s tím rozdílem, že kauce je ve výši $1 \%$ předpokládané hodnoty předmětu koncesní smlouvy, nejméně ve výši 50000 Kč, nejvýše však 2000000 Kč. V případě návrhu na uložení zákazu plnění smlouvy je navrhovatel povinen složit kauci ve výši 100000 Kč. ${ }^{4}$ Pokuty za správní delikty mohou dosáhnout až výše 10000000 , v prŕípadě zákazu účasti v koncesním řízení je zákaz platný 3 roky pro smlouvy s hodnotou plnění do 20000000.

\footnotetext{
${ }^{2} \$ 112$ zákona č. 137/2006 Sb.

3 \$115 zákona č. 137/2006 Sb.

4 § 24c zákona č. 139/2006 Sb.
} 


\section{Ochrana hospodářské soutěže}

Hospodářská soutěž představuje základní mechanismus fungování tržní ekonomiky, zvyšuje konkurenceschopnost, ekonomický růst, výkonnost ekonomiky, přispívá k podpoře inovací a snižuje náklady (Pellešová, 2008). Hospodářská soutěž může být narušována různými způsoby. Lze je rozdělit do dvou obsáhlých skupin. První z nich lze nazvat jako nekalé jednání, kam náleží např. klamavé označování zboží a služeb, parazitování na pověsti závodu, výrobku či služeb jiného soutěžitele, podplácení atd. Danou problematikou se zabývá podrobně občanský zákoník č. 89/2012 Sb. v části 4 Relativní majetková práva, Hlava III Závazky z deliktů, díl 2 Zneužití a omezení soutěže a řeší ji soudy občanskoprávního charakteru. Druhou skupinu tvoří protisoutěžní jednání, kam se řadí dohody narušující hospodářskou soutěž tzv. kartely, zneužití dominantního postavení a spojování soutěžitelů. Od roku 2012 má ÚOHS také svěřen dohled na orgány veřejné správy, které nesmí svou podporou zvýhodnit určitého soutěžitele či jiným způsobem narušit hospodářskou soutěž. Správním řízením týkající se nedovoleného narušování hospodářské soutěže se zabývají antimonopolní úrady. V ČR upravuje problematiku hospodářské soutěže zákon o obchodních korporacích č. 90/2012 Sb. a její ochranu zákon č. 143/2001 Sb., o ochraně hospodářské soutěže a o změně některých zákonů (dále jen „ÚOHS“).

K zakázaným dohodám se řadí zejména ty, jejichž cílem nebo výsledkem je narušení hospodářské soutěže a tím pádem také snížení blahobytu spotřebitelů, protože obsahují ujednání např. o prŕímém či nepř́ímém určení cen, omezení či kontrole výroby, výzkumu, rozdělení trhu či nákupních zdrojů atd. ${ }^{5}$ Dohody o rozdělení trhu či určení cen jsou označovány jako „tvrdé kartely“. Dohody uzavírány mezi soutěžiteli působící na stejné úrovni trhu zboží jsou nazývány jako horizontální dohody, naopak soutěžitelé z různých úrovní trhu mezi sebou uzavírají tzv. vertikální dohody. K horizontálním dohodám také náleží smíšené dohody uzavřená mezi soutěžiteli působící současně na horizontální i vertikální úrovni trhu zboží.

Dominantní postavení zaujímá soutěžitel či více soutěžitelů, kteří díky své tržní síle, mohou na vymezeném relevantním trhu ve velké míře uplatňovat své nezávislé jednání bez ohledu na jiné soutěžitele či spotřebitele. Dominantní postavení není na trhu dosaženo, pokud ve stanoveném období soutěžitel či soutěžitelé, v případě společné dominance, dosáhli menší než $40 \%$ tržní podíl. K praktikám dominantního postavení patří např. vázání odběru plnění, které s původním předmětem smlouvy vůbec nesouvisí, zastavení či omezení výroby, odbytu, výzkumu na úkor spotřebitelů, dlouhodobá nabídka a prodej zboží a služeb za neúměrně nízké ceny s cílem narušit fungování hospodářské soutěže, uplatněný rozdílných podmínek vůči účastníkům trhu při shodném plnění za účelem jejich znevýhodnění atd. ${ }^{6}$ ÚOHS uplatňuje přísnější postup vůči soutěžitelům, kteří zaujímají dominantní postavení na trhu, než vůči těm, kteří se na něm pohybují jen okrajově. V situaci, kdy soutěžitel zaujímá na vymezeném relevantním trhu dominantní postavení, ale chová se konkurenčně, nelze dané jednání považovat za zákonem zakázaný postup. Dominance na trhu může být ale v některých př́padech výhodná i pro spotřebitele - velikost podniku a jeho postavení na trhu mưže v některých př́ípadech vést $\mathrm{k}$ dosažení větší efektivnosti a tím i ke snížení spotřebitelských cen (Pelc, 1995). Spojování soutěžitelů lze definovat jakou fůzi dvou a více doposud samostatně fungujících soutěžitelů na daném trhu. Jedná se o obvyklý jev, kdy se soutěžitelé s menší působností stávají součástí těch, kteří disponují větší mocí na trhu, s cílem upevnění a rozššřrení svého postavení. Pokud by díky tomuto spojení mělo dojít k narušení hospodářské soutěže, jsou ze strany fúzujících firem přijímány různé závazky. Až posléze dojde k povolení

\footnotetext{
${ }^{5} \S 3$ zákona č. 143/2001 Sb.

6 \$11 zákona č. 143/2001 Sb.
} 
fúze. Může se také stát, že navrhovaná fúze není ze strany ÚOHS vůbec povolena. Cílem takového rozhodnutí není znemožnění realizace podnikatelských plánů jednotlivých soutěžitelů, nýbrž ochrana hospodářské soutěže. ${ }^{7}$

Je pochopitelné, že ve výše uvedené problematice hrají antimonopolní úřady nezastupitelnou roli. Velmi důležitá je také jejich spolupráce s dalšími významnými mezinárodními institucemi (Evropská komise - Generální ředitelství Competition, OECD - soutěžní výbor OECD, WTO, UNCTAD atd.) a rovněž seskupení jednotlivých antimonopolních úřadů na různých úrovních (International Competition Network, European Competition Network, European Competition Authorities).

\section{Pokuty udělené Úřadem v prvostupňovém rozhodnutí}

Jedním z důležitých ukazatelů činnosti úřadu je výše udělených pokut v prvostupňovém řízení. Na základě zákona č. 500/2004 Sb., je s účastníkem (ky) zahájeno správní řízení. Proti rozhodnutí Úřadu lze podat rozklad. O rozkladu rozhoduje ředitel Úřadu na základě podkladů poskytnutých sekcí druhostupňového rozhodování.

Obrázek 1: Pokuty udělené úřadem v prvostupňovém rozhodnutí v oblasti veřejných zakázek a hospodářské soutěže

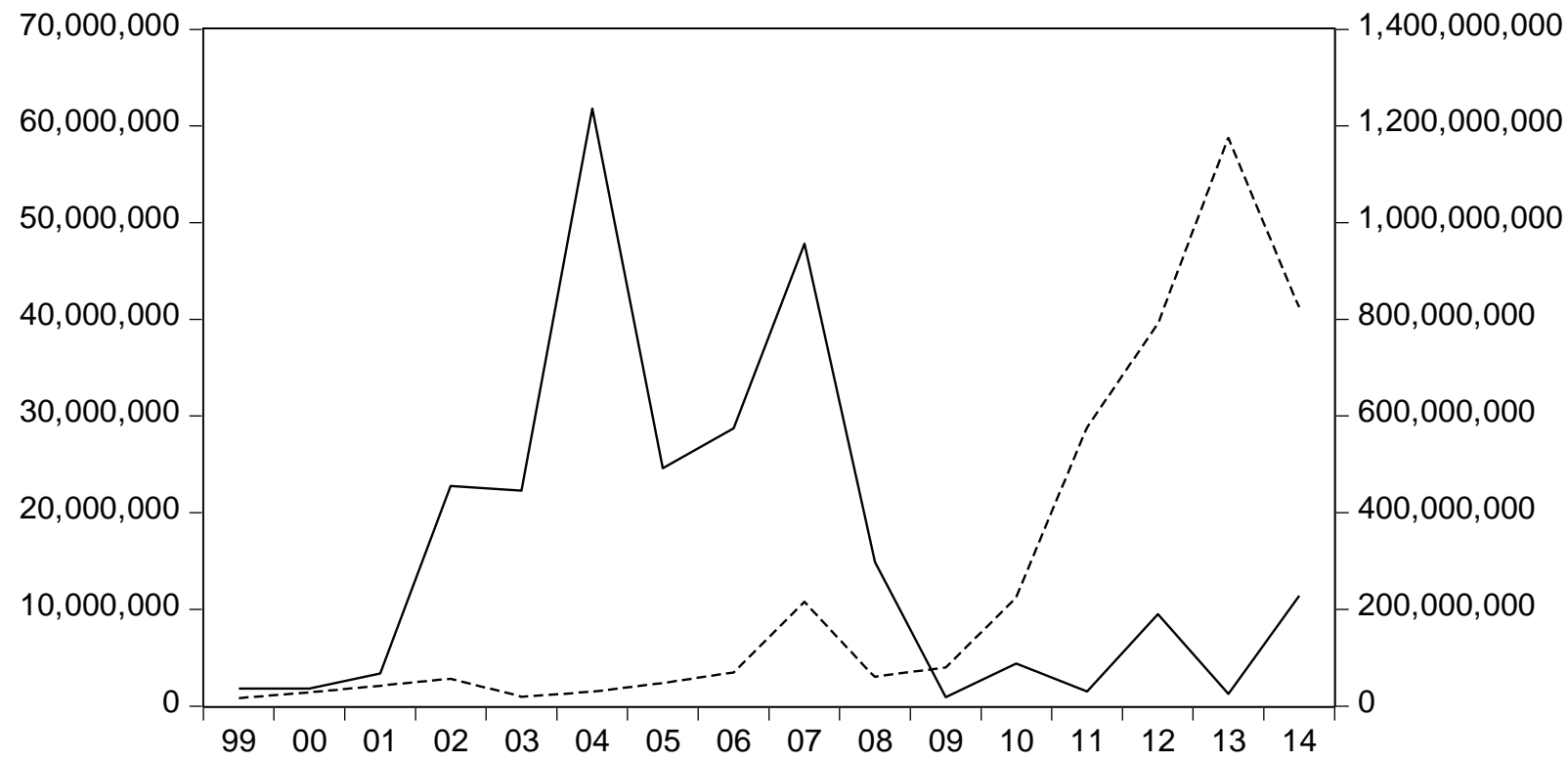

$$
\begin{aligned}
& \text {---- Výše uložených sankcí vl. stupni pro veřejné zakázky } \\
& \text { — Výše uložených sankcí vl. stupni pro hospodářskou soutěž }
\end{aligned}
$$

Zdroj: Webový portál ÚOHS: Výroční zprávy [online] [vid. 31. 3. 2015]. Dostupné z: www.uohs.cz/ cs/informacni-centrum/vyrocni-zpravy.html, vlastní úprava

Z obrázku č. 1 je u pokut uložených v prvostupňovém řízení u hospodářské soutěže patrný nárůst $\mathrm{v}$ roce 2004 a $\mathrm{v}$ roce 2007. Výkyv v roce 2004 je způsoben pokutou ve výši 484,000,000 Kč, která byla udělena všem stavebním spořitelnám působících na trhu ČR. Stavební spořitelny od roku 1997 vyměňovaly hlavně údaje o počtu uzavřených smluv. $\mathrm{Na}$ základě toho byly Úřadem nařčeni, že tato dohoda následně v roce 1999 vytvořila předpoklady pro zakázané jednání ve vzájemné shodě při stanovování poplatků za vedení účtů stavebního spoření a $\mathrm{v}$ př́ípadě pěti účastníků řízení rovněž při zavedení rozdílného

\footnotetext{
${ }^{7} \S 12$ zákona č. 143/2001 Sb.
} 
zpoplatnění vedení účtu stavebního spoření u nových a starších smluv o stavebním spoření, resp. zavedení tzv. poplatku za úrokové zvýhodnění pro starší smlouvy ${ }^{8}$. Proti této pokutě byl podán rozklad. Předseda úřadu následně rozhodnutí zrušil a vrátil správnímu orgánu prvního stupně. Ten v roce 2005 opět vydal rozhodnutí o pokutě v celkové výši 201,000,000 Kč. Po podání druhého rozkladu byla věc opět hodnocena správním orgánem prvního stupně, který rozhodl o pokutě 55,000,000 Kč. Tato pokuta byla po rozkladu potvrzena předsedou Úřadu a následně byla stavebními spořitelnami podána žaloba ke Krajskému soudu v Brně. Ten svým rozsudkem v roce 2008 pokuty zrušil. Úřad podal kasační stížnost k Nejvyššímu správnímu soudu, který v roce 2011 kasační stížnost zamítl. Další velkou pokutou v roce 2004 byla pokuta v oblasti zneužití dominantního postavení na trhu pro firmu Český Telecom a.s. ve výši 90,000,000 za znemožnění alternativním operátorům nabízet koncovým zákazníkům služby ADSL za srovnatelných podmínek. Český Telecom podal rozklad, kde byla pokuta potvrzena a zaplacena ${ }^{9}$.

V roce 2007 tvoří výkyv jediná pokuta $v$ oblasti kartelu o rozdělení trhu udělená šestnácti nadnárodním strojírenským firmám, které si mezi sebou rozdělily trh tzv. plynem izolovaného spínacího ústrojí. Př́ípad je zajímavý rovněž tím, že byly sankcionovány $\mathrm{v}$ historii vůbec poprvé i firmy, které v České republice nepůsobily. Pokuta byla pravomocná ${ }^{10}$.

V oblasti veřejných zakázek je zřetelný setrvalý nárůst začínající v roce 2009 , kdy byly uděleny pokuty ve výši 3,997,000 Kč a maxima dosáhly v roce 2013 a to výše 58,761,000 Kč. Historicky nejvyšší pokutu dostala společnost České dráhy a.s. a to ve výši 25,000,000 Kč.

Obrázek 2: Průměrná výše pokuty udělená Úřadem v prvostupňovém rozhodnutí v oblasti veřejných zakázek a hospodářské soutěže

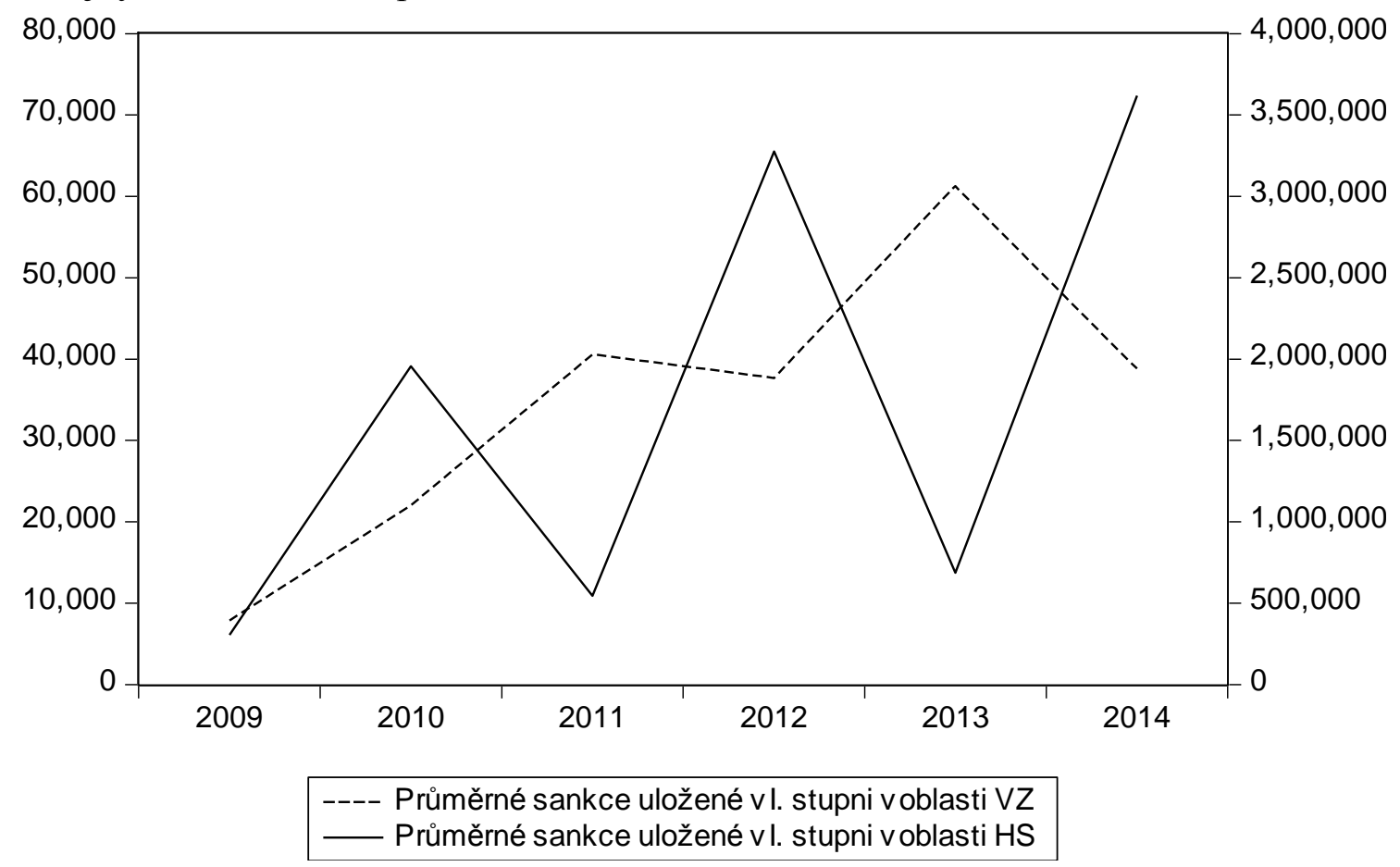

Zdroj: Webový portál ÚOHS: Výroční zprávy [online] [vid. 31. 3. 2015]. Dostupné z: www.uohs.cz/ cs/informacni-centrum/vyrocni-zpravy.html, vlastní úprava

\footnotetext{
${ }^{8}$ Výroční zpráva úřadu pro ochranu hospodářské soutěže, 2004

${ }^{9}$ Rozsudek Krajského soudu v Brně ze dne 16. 6. 2009, č. j. 62 Ca 5/2007 - 72

${ }^{10}$ Webový portál ÚOHS: Výroční zpráva 2007 [online][vid. 14. 10. 2015]. Dostupné z: http://www.uohs.cz/ cs/informacni-centrum/vyrocni-zpravy.html.
} 
Z obrázku č. 2 je patrný trend postupného zvyšování průměrné pokuty udělené v prvním stupni v oblasti veřejných zakázek. Kromě Českých drah a.s. dostala ještě v roce 2013 pokutu Armádní servisní ve výši 4,000,000 Kč a Úřad vlády ČR ve výši 1,200,000 Kč. V roce 2012 byly nejvyšší pokuty uděleny Hlavnímu městu Praha ve výši 5,000,000 Kč a Severočeské vodárenské společnosti ve stejné výši.

Z analýzy pokut udělených úřadem v prvostupňovém řízení jednoznačně vyplývá, že v oblasti veřejných zakázek je patrný výrazný rostoucí trend počínaje rokem 2009, prakticky stejně kopírovaný průměrnou výší pokut v prvostupňovém řízení. V oblasti hospodářské soutěže je naopak patrný jistý stabilizační trend po letech 2004-2007, kdy výše udělených pokut dosahovala maximální výše v historii Úřadu.

\section{Správní řízení v oblasti veřejných zakázek a hospodářské soutěže}

Následující kapitola je věnována ukazatelům a hodnotám týkající se správních rrízení, které probíhají na Úřadě v oblasti veřejných zakázek a hospodářské soutěže, včetně jejich vzájemného srovnání.

Obrázek 3: Počet zahájených správních řízení v oblasti veřejných zakázek a hospodářské soutěže

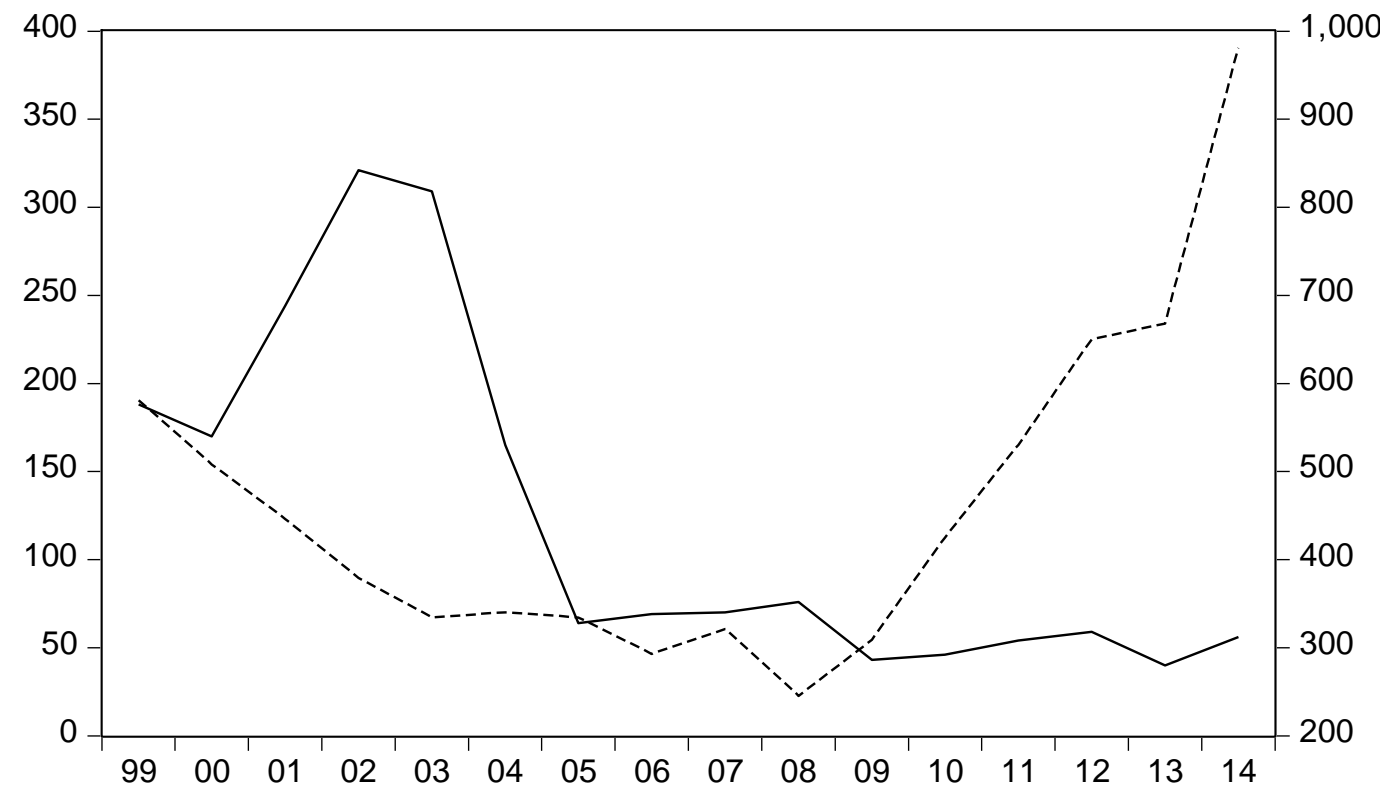

--- Počet zahájených správních řízení HS

Zdroj: Webový portál ÚOHS: Výroční zprávy [online] [vid. 10. 3. 2015]. Dostupné z: www.uohs.cz/ cs/informacni-centrum/vyrocni-zpravy.html, vlastní úprava

Z obrázku č. 3 je zřejmá převaha v počtu zahájených správních řízení v oblasti veřejných zakázek ve srovnání s hospodářskou soutěží. Jak je patrné, že i v posledních letech data vykazující rostoucí tendenci zahájených správních řízení v oblasti veřejných zakázek, načež v oblasti hospodářské soutěže spíše převažuje vyrovnaný trend. Lze také říci, že v oblasti veřejných zakázek naproti hospodářské soutěže je realizováno více výběrových řízení, a tím pádem je zde výskyt pochybení (např. nepřiměřené (diskriminační) nastavení kvalifikačních předpokladů, neoprávněné zrušení zadávacího řízení zadavatelem, porušení uveřejňovaných povinností atd.), a tím také následně zahájených správních řízení vyšší. V sekci hospodářské soutěže jednoznačně převažují zahájená správní řízení týkající se fúzí, jelikož je to jediný 
způsob, jak lze spojování společností schválit, a lze říci, že zájem v této oblasti vykazuje rostoucí trend. Nejvyšší počet zahájených správních rrízení v oblasti hospodářské soutěže byl dosažen v roce 2003 , v celkové výši 283 , z toho byly správní řízení týkající se fúzí v hodnotě 239. V oblasti veřejných zakázek byla nejvyšší hodnota dosažena v roce 2014 , a to v celkové výši 981 správních ř́zení. U veřejných zakázek v celé časové řadě výrazně převažují správní řízení zahájená na návrh. Propad u hospodářské soutěže byl zaznamenán v roce 2013, kdy bylo zahájeno jen 40 správních řízení, v oblasti veřejných zakázek byl tento pokles vykázán v roce 2008. Došlo k zahájení 245 správních řízení. Převaha správních řízení v oblasti hospodářské soutěže v letech 2000 - 2008 je dána hlavně počtem řízení v oblasti spojování podniků. Velký nárůst počtu správních řízení v oblasti veřejných zakázek je způsoben nejen novelami Zákona o veřejných zakázkách, kdy byla zvýšena maximální výše pokut udělovaných Úřadem, ale také zvýšením podnětů od veřejnosti.

Největší počet vydaných rozhodnutí v oblasti hospodářské soutěže byl v roce 2014 s celkovým počtem 63 , ve stejném roce bylo také v oblasti veřejných zakázek vydáno nejvíce rozhodnutí, celkem 1063 rozhodnutí. Nejmenšího počtu v první oblasti bylo dosaženo v roce 2013, kdy bylo vypracováno 37 rozhodnutí, u veřejných zakázek se jedná za dané sledované období o rok 2009, kdy Úřad vydal 508 rozhodnutí. Kolísavý trend týkající se počtu vydaných rozhodnutí I. stupně ve srovnání s počtem zahájených správních řízení může být také způsoben různou délkou trvání jednotlivých ř́zení $\mathrm{s}$ ohledem na složitost prípadu, shromažd'ování podkladů, prokazování porušení soutěžních pravidel, vyslýchání svědků, získávání důkazů atd.

Obrázek 4: Počet rozkladů podaných proti rozhodnutím I. stupně v oblasti veřejných zakázek a hospodářské soutěže

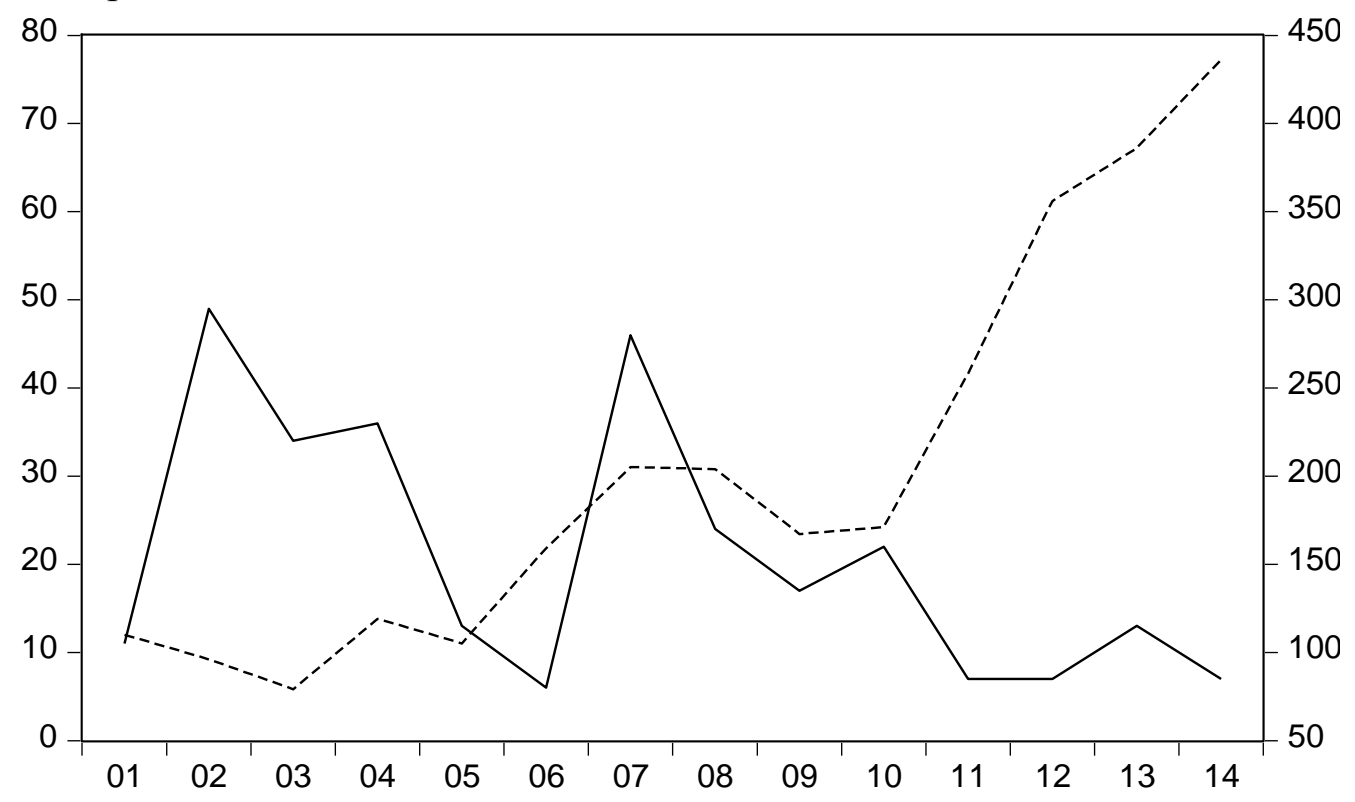

— Počet rozkladů podaných proti rozhodnutím I. stupně v oblasti HS

---- Počet rozkladů podaných proti rozhodnutím I. stupně voblasti VZ

Zdroj: Webový portál ÚOHS: Výroční zprávy [online] [vid. 10. 3. 2015]. Dostupné z: www.uohs.cz/ cs/informacni-centrum/vyrocni-zpravy.html, vlastní úprava

Obrázek č. 4 zobrazuje rostoucí trend v počtu rozkladů podaných proti rozhodnutím I. stupně v oblasti veřejných zakázek ve srovnání s hospodářskou soutěží, kde je zaznamenána spíše klesající tendence. Rozhodnutí I. stupně je možné napadnout rozkladem přímo k předsedovi 
Úřadu, který o něm rozhodne ve II. stupni. Můžou nastat dvě situace, bud' předseda námitkám rozkladu vyhoví, rozhodnutí I. stupně zruší a celý př́ípad vrátí k dalšímu projednání. V opačném př́ípadě rozklad zamítne a potvrdí rozhodnutí I. stupně. V některých př́padech dochází také k částečnému zrušení či změně napadeného rozhodnutí. Lze říci, že klesající trend podaných rozkladů vypovídá o zkvalitnění rozhodnutí I. stupně. Nejvíce rozkladů týkající se hospodářské soutěže bylo podáno v roce $2002 \mathrm{~s}$ celkovým počtem 49 , u veřejných zakázek se jedná o rok 2014, kdy bylo zaznamenáno celkem 436 rozkladů. Naopak nejméně rozkladů bylo v první oblasti evidováno v roce 2006 s celkovým počtem 6 rozkladů, u veřejných zakázek to byl rok 2003, kdy bylo podáno 79 rozkladů.

Obrázek 5: Počet vydaných rozhodnutí II. stupně v oblasti veřejných zakázek a hospodářské soutěže

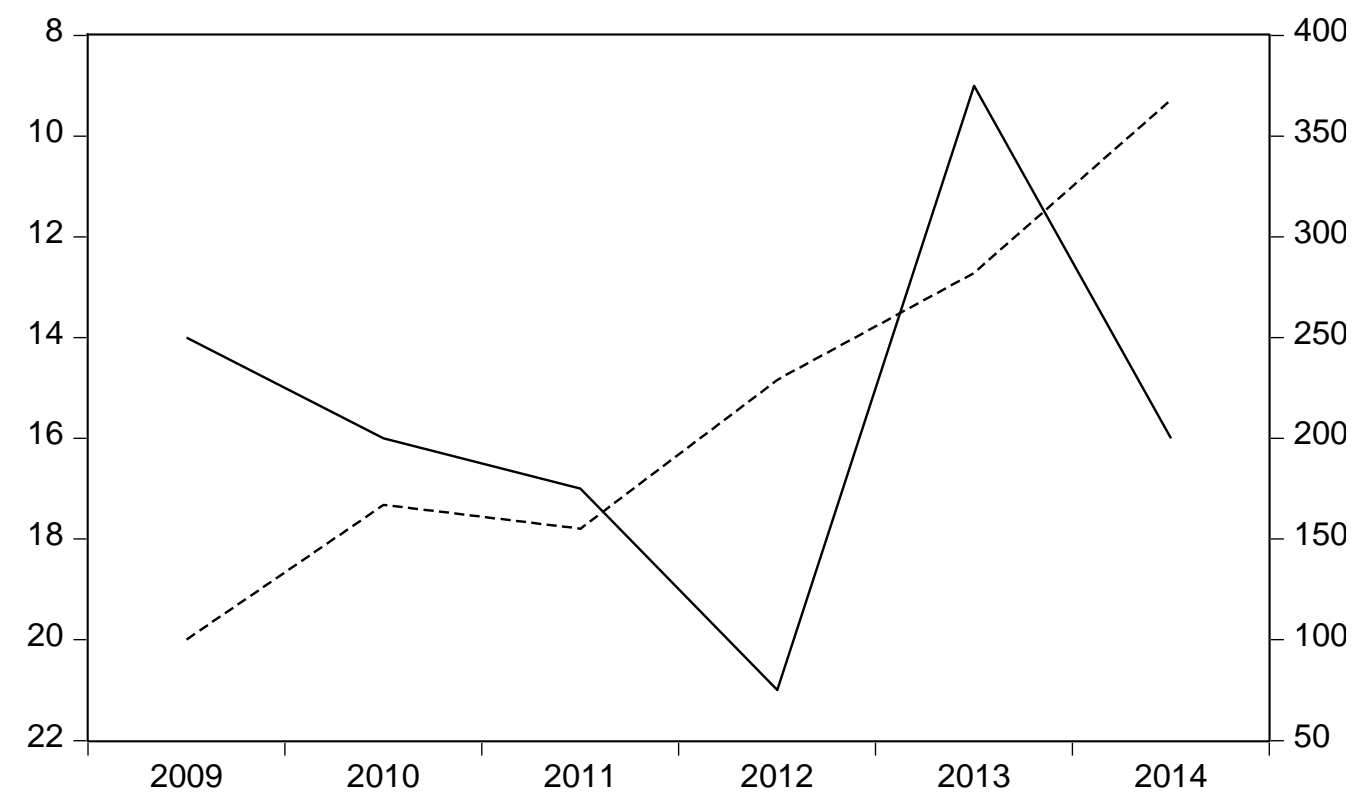

- Počet vydaných rozhodnutí II. stupně v oblasti HS
---- Počet vydaných rozhodnutí Il. stupně v oblasti VZ

Zdroj: Webový portál ÚOHS: Výroční zprávy [online] [vid. 6. 6. 2015]. Dostupné z: www.uohs.cz/ cs/informacni-centrum/vyrocni-zpravy.html, vlastní úprava

Z obrázku č. 5 vyplývá rostoucí tendence v počtu vydaných rozhodnutí II. stupně v obou oblastech. Je však zřetelné, že v oblasti veřejných zakázek se jedná o podstatně jiný objem vydaných rozhodnutí II. stupně ve srovnání s hospodářskou soutěží. Nejvíce rozhodnutí II. stupně bylo vydáno $\mathrm{v}$ oblasti hospodářské soutěže $\mathrm{v}$ roce 2012, s celkovým počtem 21 , u veřejných zakázek se jedná o rok 2014, kdy bylo evidováno 368 rozhodnutí. Naopak nejméně rozhodnutí bylo v prvním případě zaznamenáno v roce 2013 ve výši 9 rozhodnutí, co se týče veřejných zakázek, jedná se o rok 2009 s celkovým počtem 100 rozhodnutí.

Proti rozhodnutí II. stupně není možné podat opravný prostředek, jedinou možností je jeho napadení žalobou u správního soudu (Krajský soud v Brně). Žaloba může být zamítnuta nebo jí může být zcela či částečně vyhověno. Rozhodnutí II. stupně je poté zrušeno a vyžadováno opětovné řízení, kde je Úřad vázán právním názorem soudu. Proti rozsudku Krajského soudu lze podat kasační stížnost k Nejvyššímu správnímu soudu, kde může být daný rozsudek zrušen či potvrzen. $\mathrm{K}$ právům účastníků řízení náleží také v př́ípadě potřeby podání stížnosti k Ústavnímu soudu. 
Tabulka 1: Nejvyšší pokuty udělené Úřadem včetně soudního rozhodnutí

\begin{tabular}{|c|c|c|}
\hline Správní ř́izení & Výše pokuty udělená Úřadem & $\begin{array}{c}\text { Výše pokuty dle soudního } \\
\text { rozhodnutí }\end{array}$ \\
\hline $\begin{array}{c}\text { 16 výrobců plynem izolovaného } \\
\text { spínacího ústrojí }\end{array}$ & $979221000 \mathrm{Kč}$ & Výše pokuty je konečná \\
\hline Kartel šesti stavebních spořitelen & $484000000 \mathrm{Kč}$ & Pokuta zrušena \\
\hline $\begin{array}{c}\text { Zneužití dominantního postavení } \\
\text { firmou RWE Transgas }\end{array}$ & $370000000 \mathrm{Kč}$ & Pokuta zrušena \\
\hline 6 distributorů pohonných hmot & $313000000 \mathrm{Kč}$ & Pokuta zrušena \\
\hline České dráhy a.s. & $270000000 \mathrm{Kč}$ & Pokuta potvrzena \\
\hline Český Telecom & $210000000 \mathrm{Kč}$ & \\
\hline
\end{tabular}

Zdroj: Úřad pro ochranu hospodářské soutěže

V Tabulce č. 1 jsou uvedeny nejvyšší pokuty udělené Úřadem. Všechny se týkají oblasti hospodářské soutěže. Je to způsobeno tím, že zatímco u veřejných zakázek je při opakovaném správním deliktu pokuta limitována 40 miliony Kč. V oblasti hospodářské soutěže je maximální výše pokuty stanovena $10 \%$ čistého obratu dosaženého za poslední účetní období. Nejvyšší pokuta v oblasti veřejných zakázek je ve výši 25 milionů Kč udělená českým drahám, a.s., a v současné době je pokuta zrušena Krajským soudem v Brně ${ }^{11}$.

\section{Schválený rozpočet Úřadu a počet zaměstnanců voblasti veřejných zakázek a hospodářské soutěž}

Následující kapitola je věnována průměrnému počtu správních rrízení na jednoho zaměstnance v jednotlivých oblastech a také schválenému rozpočtu pro daný Úřad.

Obrázek 6: Průměrný počet správních řízení na jednoho zaměstnance v oblasti veřejných zakázek a hospodářské soutěže

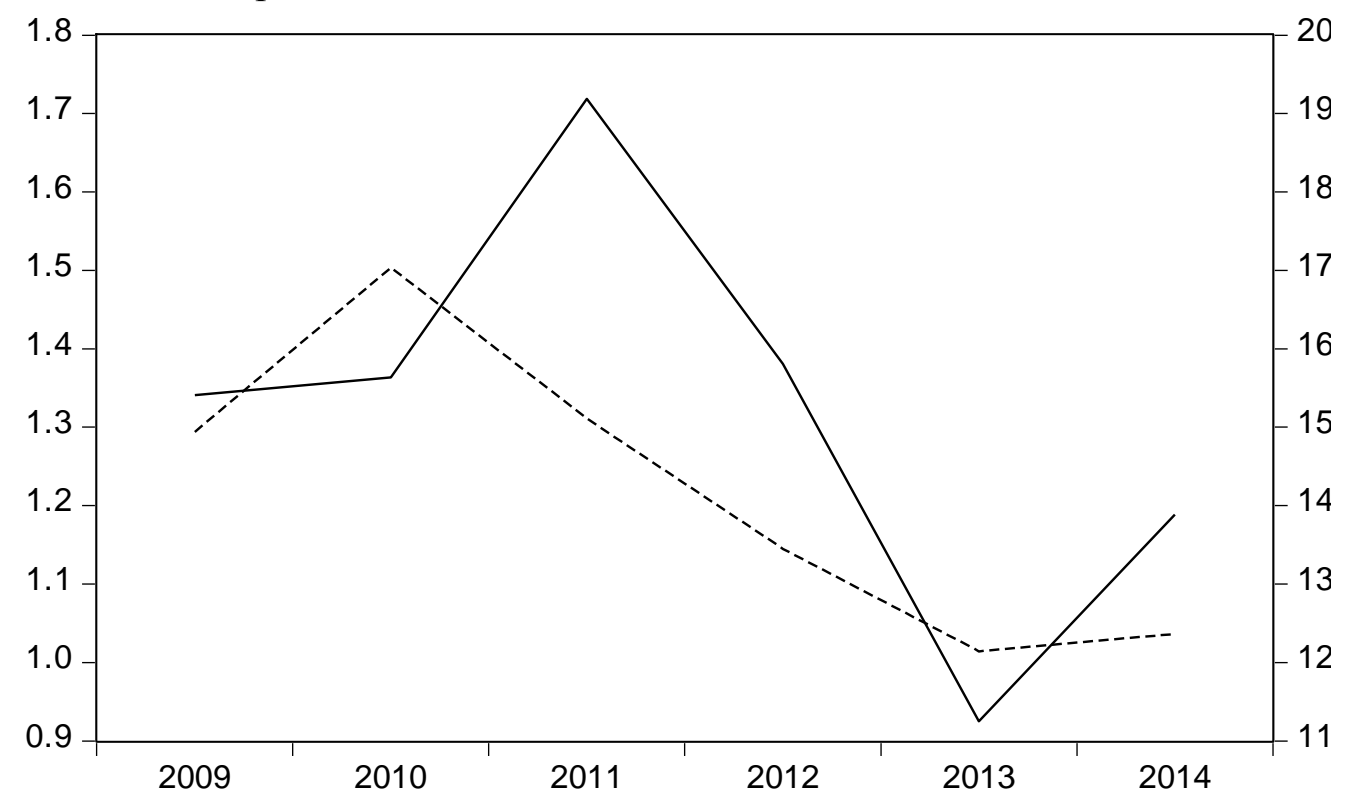

- Průměrný počet správních řízení na jednoho zaměstnance voblasti HS

---- Průměrný počet správních řizení na jednoho zaměstnance voblasti VZ

Zdroj: Webový portál ÚOHS: Výroční zprávy [online] [vid. 31. 3. 2015]. Dostupné z: www.uohs.cz/ cs/informacni-centrum/vyrocni-zpravy.html, vlastní úprava

\footnotetext{
${ }^{11}$ Nejvy̌̌ší kontrolní úřad
} 
Obrázek č. 6 jasně zobrazuje, že zatímco na jednoho zaměstnance sekce zabývající se hospodářskou soutěží připadá v průměru 1,8 správního řízení I. stupně, tak v oblasti veřejných zakázek to je max. 17 správních řízení. Za sledované období bylo nejvyššího počtu zaměstnanců $\mathrm{v}$ oblasti veřejných zakázek dosaženo v roce 2014 s celkovým počtem 86 osob. V oblasti hospodářské soutěže se jedná taktéž o rok 2014, kdy v dané oblasti pracovalo 53 osob. Nejnižší počet zaměstnanců v první oblasti byl zaznamenán v roce 2007 a 2010, v celkové výši 30, u hospodářské soutěže se jedná o rok 2011, kdy zde pracovalo 32 osob.

Obrázek 7: Schválený rozpočet Úřadu a celkový počet zaměstnanců

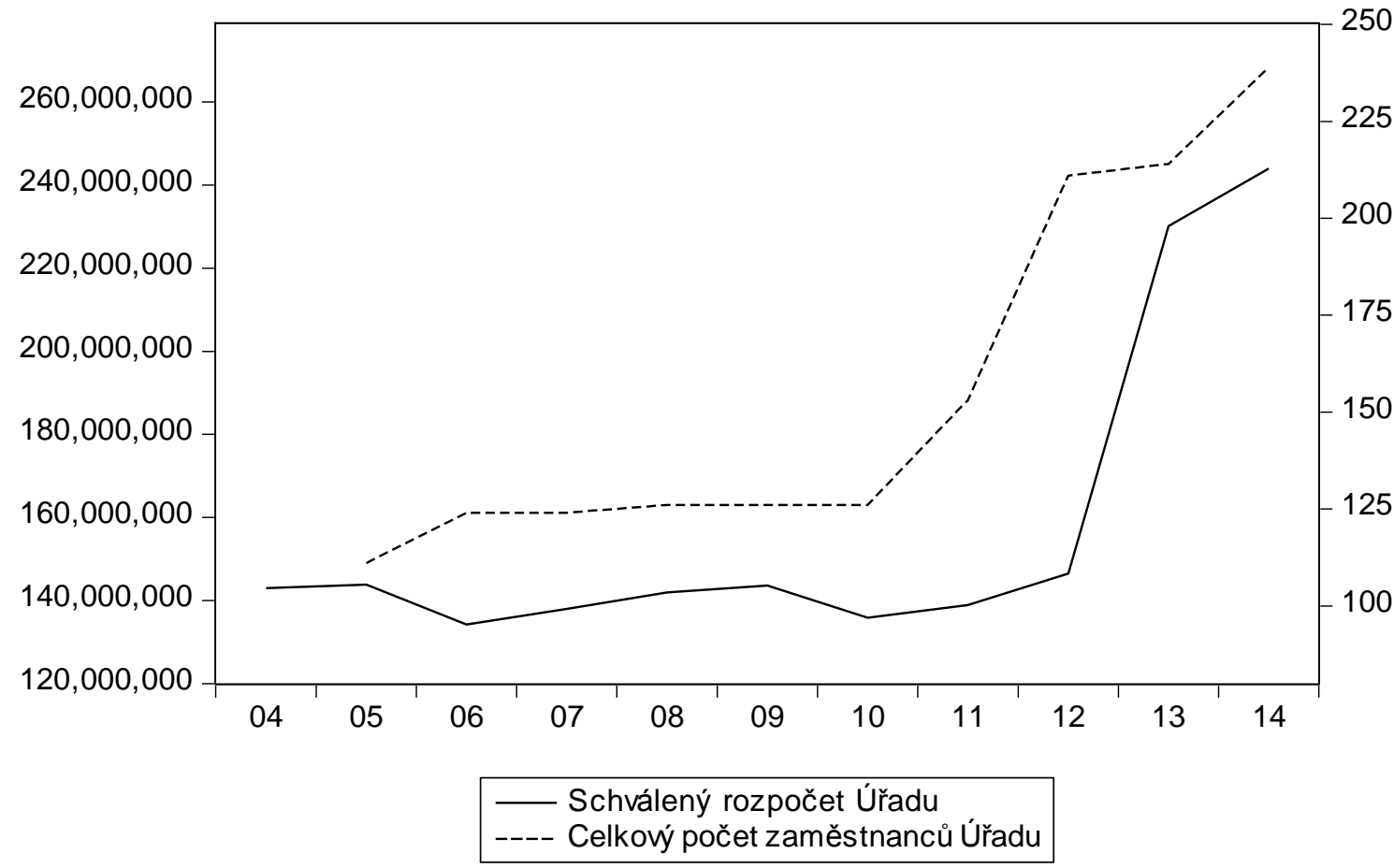

Zdroj: Webový portál ÚOHS: Výroční zprávy [online] [vid. 3. 5. 2015]. Dostupné z: www.uohs.cz/ cs/informacni-centrum/vyrocni-zpravy.html, vlastní úprava

Lze říci, že Obrázek č. 7, který zobrazuje rostoucí trend schváleného rozpočtu Úřadu je jakýmsi odrazem také zvyšujícího se počtu přijímaných zaměstnanců. Je pochopitelné, že s nárůstem počtu zaměstnanců jsou náklady na veškerou agendu a procesy vyšší. Př́ijem nových zaměstnanců lze přisoudit zejména rozšiřujícím se legislativním požadavkům a nárokům, které se týkají problematik řešených Úřadem a zejména také rozšířrením činnosti a působnosti v dalších oblastech, ve kterých začal Úřad působit. Nejvyšší schválený rozpočet byl v roce 2014 ve výši 244.015.994,- CZK, k výraznému nárůstu rozpočtu došlo v roce 2013, kdy byl schválen ve výši 230.187.000,- CZK oproti roku 2012, kdy dosahoval částky 146.516.000,- CZK. Nejvíce zaměstnanců měl Úřad za sledované období v roce 2014 v celkové výši 239 osob, naopak nejméně osob bylo na dané instituce zaměstnáno v roce 2005, tj. 111 osob. Rok 2011 pro ÚOHS znamenal zásadní změny na personální úrovni. Dlouhodobá a detailní příprava na novelu zákona o veřejných zakázkách, obsahující velké množství významných změn, znamenala zvyšování počtu zaměstnanců. Došlo k navýšení limitu kmenových zaměstnanců z původních 126 na 153. Noví zaměstnanci nastoupili především do Sekce veřejných zakázek. Nábor nových zaměstnanců pokračoval kontinuálně i v dalších letech. 


\section{Závěr}

Úřad pro ochranu hospodářské soutěže má nezastupitelnou roli nejen v dohledu nad ochranou hospodářské soutěže, ale i nad veřejnými zakázkami. Prakticky od počátku sledovaného období v roce 1999 byl vyšší počet zahájených správních řízení v oblasti veřejných zakázek nad počtem zahájených správních rrízení v oblasti hospodářské soutěže. Tento trend je patrný prakticky ve všech oblastech, které se týkají správních řízení. Opačná situace je ve výši uložených sankcí, kdy z velké části dominují pokuty udělené Úřadem v oblasti hospodářské soutěže, ale to je dáno především maximálním stropem sankce, kdy v oblasti hospodářské soutěže je vyšší než v oblasti veřejných zakázek. Dále je patrný obrovský růstový trend v oblasti správních řízení týkajících se oblasti veřejných zakázek. Naproti tomu je ve správních řízeních $\mathrm{v}$ oblasti hospodářské soutěže vidět jistý stabilizační trend, kdy jejich počet zůstává na přibližně stejné výši. Je také nutné podotknout, že v této oblasti tvoří většinu správních rrízení týkající se spojování soutěžitelů.

S velkým nárůstem správních řízení úzce souvisí navyšování rozpočtu Úřadu a hlavně také od roku 2011 setrvalý nárůst počtu zaměstnanců. V organizační struktuře je tudíž, co se týče počtu zaměstnanců v současnosti největší sekce veřejných zakázek. Počet správních řízení v oblasti veřejných zakázek k počtu zaměstnanců sekce veřejných zakázek kolísá průměrně od 8 do 17, naproti tomu $\mathrm{v}$ oblasti hospodářské soutěže nepřevýší počet správních řízení na jednoho zaměstnance hodnotu $1,7 \mathrm{v}$ letech $2009-2014^{12}$.

\section{Literatura}

[1] BERGEROVÁ, E., 2005. Veřejné zakázky v České republice. 1. vyd. Praha: Eurolex Bohemia. ISBN 80-86861-84-8.

[2] PELC, V., 1995. Hospodářská soutěž. 1.vyd. Praha: Grada Publishing. ISBN 80-7169124-0.

[3] PELLEŠOVÁ, P., 2008. Role Úřadu pro ochranu hospodářské soutěže v politice tvorby a ochrany konkurenčního prostředi [online]. [vid. 20. ř́́jna. 2015]. Dostupné z: mpra.ub.uni-muenchen.de/12093/3/MPRA_paper_12093.pdf

[4] PRAVEC, J., 2014. Šrouby nad veřejnými zakázkami povolují. Ekonom: týdeník vydavatelství Economia, LVIII, 40, 14-17.

[5] RAUS, D. a R. NERUDA, 2005. Hospodářská soutěž po vstupu ČR do EU. 1.vyd. Brno: CP Books, a. s. ISBN 80-251-0394-3.

[6] TRANSPARENCY INTERNATIONAL, 2007. Veřejné zakázky v České republice: korupce nebo transparentnost? [online]. Praha: Transparency International. Dostupné $\quad \mathrm{z}: \quad$ www.transparency.cz/verejne-zakazky-ceske-republice-korupcetransparentnost/

[7] ÚOHS. Výroční zprávy [online]. [vid. 20. srpna. 2015]. Dostupné z: www.uohs.cz/ cs/informacni-centrum/vyrocni-zpravy.html

[8] Zákon č. 137/2006 Sb., o veřejných zakázkách. Portál veřejné správy [online]. [vid. 20. června 2015]. Dostupné z: portal.gov.cz/app/zakony/zakonPar.jsp?idBiblio $=62419 \& \mathrm{nr}=137 \sim 2 \mathrm{~F} 2006 \& \mathrm{rpp}=15 \#$ local-content

\footnotetext{
${ }^{12}$ Vlastní výpočet dle: ÚOHS. Výroční zprávy [online]. [vid. 20. 6. 2015]. Dostupné z: www.uohs.cz/cs/ informacni-centrum/vyrocni-zpravy.html
} 
[9] Zákon č. 139/2006 Sb., o koncesních smlouvách a koncesním řízení. Portál veřejné správy [online]. [vid. 20. června 2015]. Dostupné z: portal.gov.cz/ app/zakony/zakonPar.jsp?idBiblio=62421\&nr=139 2F2006\&rpp=15\#local-content

[10] Zákon č. 143/2001 Sb., o ochraně hospodářské soutěže. Portál verejné správy [online]. [vid. 20. června 2015]. Dostupné z: portal.gov.cz/app/zakony/zakonPar.jsp? idBiblio=51286\&nr=143 2F2001\&rpp=15\#local-content

[11] Zákon č. 273/1996 Sb., o působnosti Úřadu pro ochranu hospodářské soutěže. Portál veřejné správy [online]. [vid. 20. června 2015]. Dostupné z: portal.gov.cz/ app/zakony/zakonPar.jsp?page=0\&idBiblio=44483\&nr=273 2F1996\&rpp=15\#localcontent 